\title{
Oral Tradition and Oral History \\ in Iceland from Settlement \\ to Present Day
}

\section{Short survey}

Wrocławski Rocznik

Historii Mówionej

Rocznik VI, 2016

ISSN 2084-0578

\section{Introduction}

Oral history has been well known in Iceland for centuries, but in a very different form than it is seen today. Poems and rhymes were passed on verbally from one generation to the next, like the Old Norse poetry, Edda poems (Ice. Eddukvæði), before being transcribed to parchment.

Traditionally, oral history as we know it today, especially before the year 2006, has not been used to a great extent in Iceland. The Centre of Oral History in Iceland was established in 2007, and has had considerable impact, not only on the collection of material, but also on introducing oral history to the public, as well as scholars. Some historians used the oral history method before 2007 , but presently it has become a more common practice in historical research.

Life experience provides access to the everyday lives of people to historians, as well as important events seen through the people's eyes. The use of oral history in Iceland is very similar to that in the United Kingdom, where historians use this as a tool to reach new sources of various marginalized groups within societies. Groups like refugees and immigrants, as well as homosexuals, had limited accessed to the media and have been almost invisible in Icelandic history, with very few written sources concerning these groups. 
In the first part of this article, I will discuss oral tradition in Iceland from the beginning of the settlement in the year 874. In the second part, I will discuss how oral history was practiced in the $20^{\text {th }}$ century, how it has changed and how the method of oral history is taught in the History Department of the University of Iceland. In the third and last part I will discuss three studies of oral history in the $21^{\text {th }}$ century in Iceland.

\section{Oral Tradition in the Past in Iceland}

In Iceland, oral tradition has been known since the early settlement in the $9^{\text {th }}$ century and before written sources were available, culture, poetry and a variety of knowledge were preserved through oral transmission. Principles and information from society were passed between generations in the form of stories and poems. Ritual and worship wrapped themselves around the spoken word, either through song or poetry. Legislation was passed and sentences were rendered, without the lawspeaker (Ice. lögsögumaður) having the law written down ${ }^{1}$.

It is believed that the parliament, the Alpingi, was established around the year 930, and the law, parliamentary session and procedural rules of an assembly were all preserved in oral transmission. Each year the lawspeaker had to recite a third of the laws of the country ${ }^{2}$.

Studies on the preservation of information have shown how long accounts or narratives can survive, even for centuries. It does not necessarily mean that the narrative is historically accurate, as stories change with each performance. Formulae were used to remember the narrative. In Iceland, you can see these formulae, like special rules for poetry, such as metre (Ice. bragarháttur), alliteration (Ice. stuðlasetning), rhyme (Ice. rím) and the rhythm of poetry (Ice. hrynjandi i kveðskap). The ancient Norse poetry, the Edda poems, and much court poetry (Ice. dróttkvæeði), were preserved in oral transmission until the $13^{\text {th }}$ century, when they were written down on parchment $^{3}$.

Another example of oral transmission in Iceland in the past centuries, is the so-called Turkish invasion. The corsairs were not from Turkey but

1 See: Handritin heima (Runes and oral transmission), www.handritinheima.is/sagan/ upphafritunar/upphaf_bokagerdar.htm (accessed November 15, 2015).

2 See: Alpingi (Parliament), 2004, http://www.althingi.is/pdf/isl.pdf (accessed November 18, 2015).

3 Handritin heima..., op. cit. 
from North Africa, Algiers, and a few of them were from Europe. The reason why it is called the Turkish invasion is because Algiers was than under the rule of the Ottoman Empire 4 . In 1627, two groups of corsairs attacked the Icelandic coast. The first group made an attack in Grindarvík, looted money and abducted people, but the other group came from Algiers and attacked the East coast, capturing 110 people, and then sailed to Vestmannaeyjar (the Westman Islands). The battle was fierce and about forty people were killed and four hundred taken captive. The people were transported to North Africa and sold into slavery, but about ten percent of them were bought back for money procured by the church and the king. Sources found on this event are based primarily on three stories. Two of these three stories are based on oral testimonies. There are the reports of Kláus Eyjólfsson, lawspeaker and farmer in Landeyjar, who wrote down the story, which he based on oral testimonies from conversations that he had with those who escaped, and his own examination of the evidence in Vestmannaeyjar. Another story is Rev. Ólafur Egilsson's Reisubók; in this book he describes how he was taken captive and shipped to Algiers, the year he stayed there and the journey back home. In this narrative, we get to know his feelings and thoughts about God, his family and the people in Algeria, who were Muslims. The third story is the story of Björn Jónsson from Skarðsá, based on the two previous narratives and letters as well as on other written sources ${ }^{5}$.

\section{Oral History in the $20^{\text {th }}$ Century}

In the $20^{\text {th }}$ century, Icelandic historians paid little attention to oral history. In recent decades, however, they have increasingly been pursuing oral sources, and there are a few signs of it, e.g. in books where the method of oral history has been used, like Togarasaga Magnúsar Runólfssonar skipstjóra, from 1983, written by historian Guðjón Friðriksson. This book gives an idea of the fisherman's standard of living in Reykjavík in the early $20^{\text {th }}$ century. The practice of oral history was mainly broadcast by the National Radio in the $20^{\text {th }}$ century. In the summer of 1983 , the National Radio recorded accounts from 30 working class people who were asked about their lives in the interwar period ${ }^{6}$.

4 E. Laxness, Icelandic saga s-ö, Reykjavík 1995, p. 94.

5 Porsteinn Helgason, Turkish invasion as memory, "Ritið“, 3 (2013), p. 120-121.

6 Jón Guðnason, On oral sources, "Saga”, 1 (1989), p. 15-16. 
In 2005, a group of people discussed amongst themselves how to develop the method of oral history within Icelandic history and a few interesting projects had been carried out. Oral history in Iceland was not as popular as in many neighboring countries over the past 25 years. Oral sources were dispersed all over the country and it was necessary to gather them together in one location. Many of them were owned by private companies, individuals, museums and institutions. It was known that various scholars and writers had also used that kind of sources in their work, but it can be said that little tradition on the use of oral history has existed among historians in their own research, so as in teaching in the History Department in University of Iceland.

The History Department has no specific courses on the method of oral history. In the B.A. program, there are three mandatory related programs in history: Making History; History of Historical Writing and Philosophy of History; and Concept of History and Presentation of Historical Work. In the first two courses, students get just a glimpse at the oral history method, but nothing more? That is much different from Iceland's neighboring countries, e.g. Malmö University in Sweden, which put oral history into their curriculum, even though it gives students a chance to become acquainted with another perspective for evaluating the past and is often more interesting for students rather than written sources. Listening to oral history interviews often better connects them with the past events than reading from paper documents.

When overseas oral sources can be obtained through libraries, history associations, museums and schools, in Iceland oral sources can now be found gathered in specific collections in the Centre for Oral History in Reykjavík. Learning oral history method helps students to distinguish different kinds and categories of sources, like primary sources and secondary sources, and to assess their value. Oral history allows students to understand the past firsthand and experience how history affects the emotions and lives of individuals. One of the aims of the present of oral history for history students is that with it they have an opportunity to use this method in their own historical research. It is a part of the debate on the objectivity

See: History, BA (courses in 2015-2016), [in:] University of Iceland Course Catalogue, https://ugla.hi.is/kennsluskra/index.php?tab=nam\&chapter $=$ namsleid $\& i d=056060$ _20156\&kennsluar=2015 (accessed November 18, 2015). 
and bias of history, memory and its limitations, as well as the interpretation

of historical information. Last year, at the History Department there were two courses that introduced students to the method of oral history. In both cases students used the method of oral history in their research in a practical way: they had to find a interviewee, make interviews and process them in a scientific way. One of the courses was thematically devoted to immigrants ("Immigrants and migration to Iceland 1900-2008") and the other to the so called Cold War ("The End of History? The Collapse of Communist Rule in Eastern Europe 1989-1991"). Moreover the History department at the University of Iceland offered a particular course on the method of oral history ${ }^{8}$.

\section{Three Examples of Oral History Studies in Iceland in the 21 st century}

Iceland has not received many refugees since 1956, which is when the first such a group arrived in Iceland. From that time and until 2015, 549 refugees had been granted asylum on the island.

In 2006, it was 50 years since those first 52 refugees came to Iceland from Hungary, fleeing the country when the Soviet army invaded Hungry in $1956^{\circ}$. This event was considered a milestone for the Icelandic society, therefore, the Centre for Oral History decided to interview those from the refugees who were still alive, register their accounts, and process their oral testimonies. On the website of the Centre for Oral History one can listen to a fragments of an interview taken with Mikael Fransson, who was among those who fled to Iceland in $1956^{10}$. He was born in Hungary in 1935 and after coming to Iceland he worked as a commercial illustrator and designer and was a pioneer in that field in Iceland. He married an Icelandic woman, and at the time when the interview was recorded he already had two grown up daughters. He was interviewed at his home, where he told the story of his actually two escapes from his country: first, during World War II and the second one in 1956. He also described how he felt when he arrived

8 Birna Björnsdóttir, Oral history and history teaching, "Saga", 2 (2008), p. 204, 206, 208, 210-211.

9 See: 50 years since Hungarian refugees came to Iceland 24.12.2006, The Red cross in Iceland, http://www.raudikrossinn.is/page/rki_frettir\&detail=1001640 (accessed October 31, 2015).

10 Hungarian refugees, Centre of Oral History, http://munnlegsaga.is/index.php? page=ungversku-flottamennirnir (accessed October 31, 2015). 
in Iceland, leaving behind everything that was familiar to him: language, country, culture, family and friends, and how his life has been since then ${ }^{11}$. Of the eleven Hungarian refugees who were still alive in 2007, unfortunately, only two people were interviewed and it is quite unlikely that any more interviews will be done in this project because of the refugees' age ${ }^{12}$.

There is another institution that has collected oral sources, but in a very different way: the National Museum of Iceland (Ice. Pjóðminjasafn Islands), which role is to increase and disseminate knowledge of the cultural heritage of the Icelandic nation from the beginnings to the present day ${ }^{13}$. The museum has sent out a questionnaire with the purpose of gathering information on the lives of "ordinary people". It's worth noting that this year Icelandic society celebrates an important anniversary - 100 years since women over 40 were eligible to vote in Iceland. On that occasion the museum is looking for sources from the public regarding the "conditions of the sexes" in Iceland from the late $2 \mathrm{O}^{\text {th }}$ century to the present day. Respondents had to submit written replies based on their memories on this topic, the answers could be as long as the authors wanted and they could submit their names if they wished, but were also permitted to remain anonymous. However, they were asked to reveal their age, gender, residence and profession. The questions regarded the following areas: study and work, home and parenting, childbirth and family size, participation in social activities and attitudes towards gender. The data gathered in this project will be registered in an electronic database and will be made available to scholars as well as to the public ${ }^{14}$.

The third study discussed here, is the investigation by Dr. Íris Ellenberger, who is an Icelandic historian. In her doctoral thesis she used oral history as a part of her research methods, studying the history of Danish

11 First refugee in Iceland, Centre of Oral History, January $9^{\text {th }}$ 2007, http://munnlegsaga. is/index.php?page=fyrsti-flottamadurinn-a-islandi (accessed November 14, 2015).

12 Collection MMS 23 - Refugee in Iceland, Centre of Oral History, 2007, http://einkaskjol.is/index.php/onmn6 (accessed November 18, 2015).

13 See: About museum, National Museum of Iceland, http:/www.thjodminjasafn.is/ um-safnid/ (accessed November 25, 2015).

14 List 122: conditions of the sexes, 2015, dispatch document, National museum of Iceland, research in progress, http://www.thjodminjasafn.is/minjar-og-rannsoknir/ thjodhattasafn/rannsoknir/rannsoknir-i-gangi/nr/4663 (accessed November 14, 2015). 
immigrants in Iceland ${ }^{15}$. In her ongoing studies she will investigate the fellowship of lesbian feminists in the $9^{\text {th }}$ decade of the last century and there are two reasons why she wants to use the oral history method in that research. The first and basic reason is the lack of written sources to this subject. Secondly the method of oral history gives her the ability to challenge a certain settled view of history ${ }^{16}$. By the mid-20 ${ }^{\text {th }}$ century, LGBT people truly were the hidden group in Icelandic society, because they were either in hiding or had moved to Denmark. In 1978 an organization "Samtökin 78 " was founded ${ }^{17}$, fighting for the rights of the LGBT community and educating the public about the matter. Prejudice against the homosexual community was very severe in Iceland in the 20 century and through the years of struggle they gain rights now comparable to heterosexual people ${ }^{18}$. The law on registered partnerships was passed by the Parliament in the 1996 and on marriages in 2010. This way equal human rights became an important Icelandic export commodity and foreign gay people migrated to Iceland. Íris Ellenberger studies how the homosexual people remember the story and those points of view are the framework of the collective memory of this group, becoming a part of national history and memory. The picture underlines that Iceland embraced those people with open arms, but it also includes a certain forgetfulness - the unpleasant memories are swept under the carpet as they are not consistent with the idea of Icelandic society as friends of human rights ${ }^{19}$. The research of Dr. Ellenberger will directly or indirectly conflict with the accounts that are the foundation of the collective memory of this group, and at the same time, on the national memory. She will use the written sources from both the archive and the media, but since the association is a marginal group it is very likely that such data is scarce. Therefore, this is a suitable opportunity to use the oral history

15 Íris Ellenberger, Danish immigrants in Iceland 19oo-1980: social status, integration and cross-nationality, Reykjavík 2013.

16 Eadem, Nations memories and oral history in the light of LGBT nationalism, Congress Memory, narrative and oral history (October 2, 2015).

1778 Associations. Association of lesbian and gay in Iceland, City Archive in Reykjavík, private archive no. 297, http://www.borgarskjalasafn.is/Portaldata/21/Resources/ borgarskjalasafn/skjalaskra/felog/Samtoekin_78 (297).pdf (accessed November 18, 2015).

18 See: Íris Ellenberger, Nations memories..., op. cit.

19 Ibidem. 
method. This will be useful in the study of conflict and different interests within marginalized groups. Method of oral history might help to break up the ideas of homosexual people at this time as a single unit with the same interests, goals and desires ${ }^{20}$.

\section{Conclusion}

In this article I gave a very brief overview of how the oral tradition and oral history that has been used in Iceland from the beginning of the settlement in 874 to the present day, when history, culture, ethics, etc. was preserved in oral transmission passed from one generation to the next. A good example of that is the Edda poems and the history of the Turkish invasion.

But practice of the oral history method is a fairly new phenomenon. Icelandic scholars did not use oral history in the first few decades of the $20^{\text {th }}$ century. However oral history has gradually gained more respect in Iceland and has become increasingly common as part of the research method and more accepted, especially over the last ten years.

This is especially true since the Centre for Oral History was established in 2007. Nevertheless, oral history has not achieved the same popularity among scholars if compared with our neighboring countries.

We can see increasing use of oral history method in Iceland; more and more academics and institutions are using this method to gather information about the "common people" and their everyday lives. Therefore, the use of oral history in Iceland is primarily history from below. Powerless or oppressed social groups receive a voice and are able to bring forth new information. 
The paper gives a short look at the development of the oral tradition in Iceland, where passing the laws and knowledge about the past events verbally from one generation to the other was a crucial way to preserve tradition and identity of the nation since the beginnings. The Author also presents how the approach to the oral history method in Iceland changed in the past few decades. It becomes more and more popular among scholars and society in general, especially since the Center for Oral History was established in Reykjavík in 2007. In the article one can read about the latest oral history projects, concerning among others ethnic and sexual minorities in Iceland, and the specificity of Icelandic approach to oral history method.
Maria

Jóhönnudóttir

Oral Tradition and Oral History in Iceland from Settlement to Present Day. Short survey 